\title{
The effects of different environmental factors on the biochemical composition of particulate organic matter in Gwangyang Bay, South Korea
}

\author{
Jang Han Lee ${ }^{1}$, Dabin Lee ${ }^{1}$, Jae Joong Kang ${ }^{1}$, Hui Tae Joo ${ }^{1}$, Jae Hyung Lee ${ }^{1}$, Ho Won Lee ${ }^{1}$, So Hyun Ahn ${ }^{1}$, \\ Chang Keun Kang ${ }^{2}$, and Sang Heon Lee ${ }^{1}$ \\ ${ }^{1}$ Department of Oceanography, Pusan National University, Geumjeong-gu, Busan 46241, Korea \\ ${ }^{2}$ School of Environmental Science and Engineering, Gwangju Institute of Science and Technology, Gwangju 500-712, Korea
}

Correspondence to: Sang Heon Lee (sanglee@pusan.ac.kr)

Received: 19 August 2016 - Discussion started: 24 August 2016

Revised: 21 February 2017 - Accepted: 17 March 2017 - Published: 7 April 2017

\begin{abstract}
The biochemical composition of particulate organic matter (POM) produced through phytoplankton photosynthesis is important in determining food quality for planktonic consumers as well as the physiological conditions of phytoplankton. Major environmental factors controlling the biochemical composition were seasonally investigated in Gwangyang Bay, South Korea, which has only natural conditions (e.g., no artificial dams). Water samples for the biochemical compositions were obtained from three different light depths $(100,30$, and $1 \%)$ mainly at three sites in Gwangyang Bay from April 2012 to April 2013. Different biochemical classes (carbohydrates, $\mathrm{CHO}$; proteins, PRT; and lipids, LIP) were extracted, and then the concentrations were determined by the optical density measured with a spectrophotometer. The highest and lowest PRT compositions among the three biochemical classes were found in April $2012(58.0 \%)$ and August $2012(21.2 \%)$, whereas the highest and lowest LIP compositions were found in August 2012 (49.0\%) and April 2012 (24.8\%), respectively. The CHO composition was recorded as high in January 2013 and remained above $25 \%$ during the study period. The calorific contents of the food material (FM) ranged from 1.0 to $6.1 \mathrm{Kcal} \mathrm{m}^{-3}$ (annual average $\pm \mathrm{SD}=2.8 \pm 1.1 \mathrm{Kcal} \mathrm{m}^{-3}$ ). Based on a Pearson's correlation coefficient analysis, a major governing factor in the biochemical composition of POM was dissolved inorganic nitrogen loading from the river input in Gwangyang Bay. In conclusion, a relatively larger amount of FM and the higher calorific contents of POM found in this study compared to other regions reflected good nutri-
\end{abstract}

tive conditions for sustaining productive shellfish and fish populations in Gwangyang Bay. Continuous observations are needed to monitor the marine ecosystem response to potential environmental perturbations in Gwangyang Bay.

\section{Introduction}

Particulate organic matter (POM), mostly from phytoplankton photosynthesis in the euphotic layer, is an important food source for planktonic consumers in water columns (Cauwet, 1978). The biochemical contents reaching the benthic environments are largely utilized by benthic organisms (Nelson and Smith, 1986; Rice et al., 1994). Therefore, POM is an essential link between surface and benthic ecosystems (Graf, 1992). Previous studies showed that the biochemical composition of the POM, including protein (PRT), lipid (LIP), and carbohydrate $(\mathrm{CHO})$ levels, could provide useful information on the nutritional value that is potentially available to consumers (Mayzaud et al, 1989; Navarro et al., 1993; Navarro and Thompson, 1995). However, previous studies mainly focused on the occurrence in the different patterns of the biochemical composition of POM. It is noteworthy to investigate how the biochemical composition of POM responds to changes in various environmental factors, such as nutrients, light, temperature, and salinity, and to assess food quantity for the higher trophic levels.

The coastal areas represent one of the world's most vital aquatic resources, supporting and providing food resources 

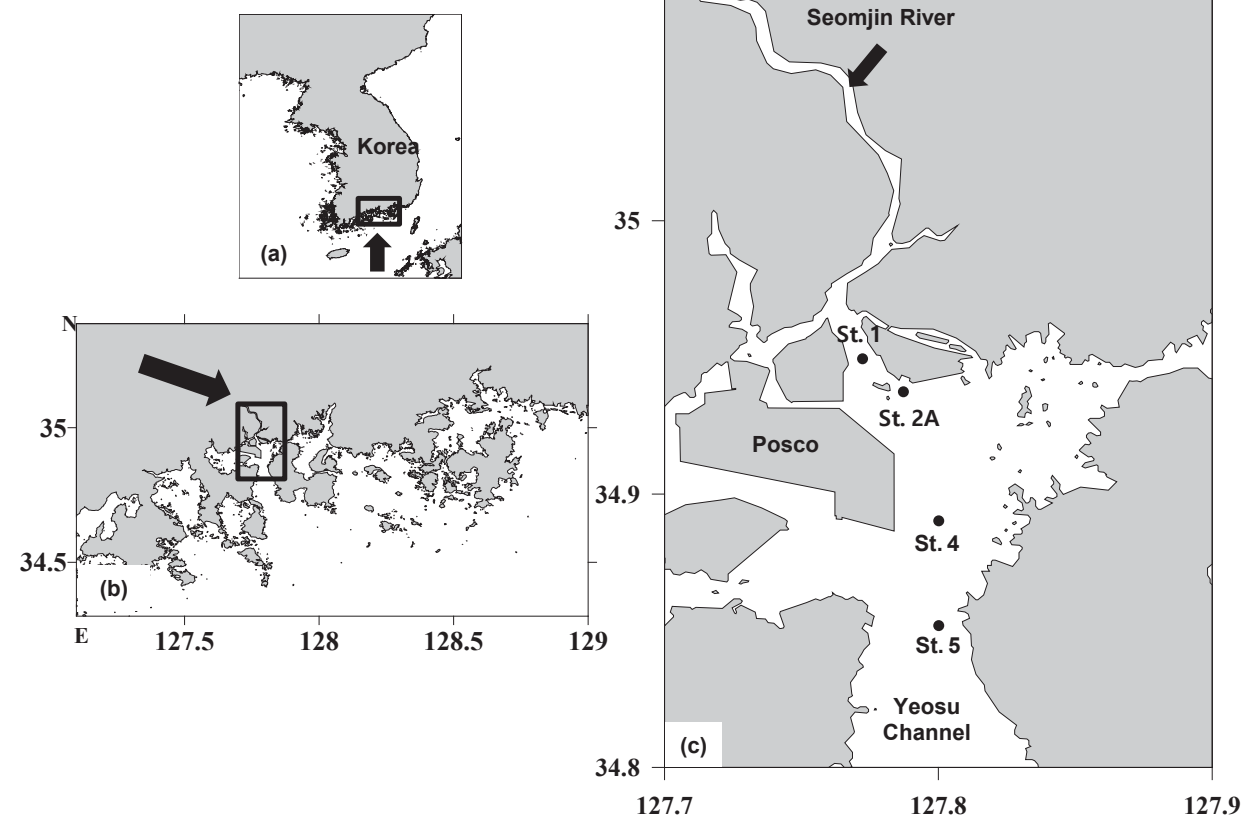

Figure 1. The sampling location in Gwangyang Bay, Korea. Maps of Korea (a), the southern coastal sea (b), and the main sampling stations (c).

and habitats for large numbers of fish and shellfish species (Kwak et al., 2012; Wetz and Yoskowitz, 2013; references therein). In Gwangyang Bay on the southern coast of Korea (Fig. 1), coastal shellfish farming and fisheries are prevalent. Over the past decades, the bay has become industrialized with the construction of a steel mill company, a power plant, and and industrial complex, and environmental disturbances have been predicted. Also, estuaries have a high short-term variability depending on many episodic events, such as freshwater inputs, tidal cycles (neap and spring), and wind (storms) (Cloern and Nichols, 1985). These anthropogenic forces and environmental changes drastically affect the estuarine habitat properties, which can cause different biochemical compositions in POM. Unfortunately, little information is available on the biochemical composition of POM in the bay. Hence, this study tested the main environmental factors determining the seasonal variation and biochemical composition of POM and assessed the quantity of food material (FM) in the bay. Physical (temperature, salinity, irradiance, river input and rainfall data), chemical (nutrients), and biological (chlorophyll $a, \mathrm{Chl} a$; particulate organic carbon, POC; and nitrogen, PON) parameters were measured in order to both characterize the origin of POM and understand their effects on the biochemical composition of POM. The aims of this study were to (1) investigate the seasonal variation in the biochemical composition of POM, (2) identify the origin of POM, and (3) determine the major governing environmental factors for the biochemical composition of POM in Gwangyang Bay, Korea.

\section{Materials and methods}

\subsection{Study site and sampling procedure}

The study site was located in Gwangyang Bay $\left(34.9^{\circ} \mathrm{N}\right.$, $127.8^{\circ} \mathrm{E}$ ) on the southern coast of Korea (Fig. 1). The total area of the bay is $230 \mathrm{~km}^{2}$ at mean sea level (Kang et al., 2003). The bay is characterized by semidiurnal tides with a maximal range of about $4.8 \mathrm{~m}$ at spring tide (Korea Hydrographic and Oceanographic Administration). Freshwater flows into the bay from the Seomjin River at the northern part of the bay (mean flow $27 \mathrm{~m}^{3} \mathrm{~s}^{-1}$; annually $1.9 \times 10^{9} \mathrm{t}$ during the study period; the National Institute of Environmental Research) and seawater enters through the narrow southern channel (Yeosu Channel).

To obtain data for the seasonal variation in POM at the euphotic depth, the field samplings were taken at three stations of the bay (St. 1 or St. 2A, St. 4, and St. 5; see Fig. 1) on a seasonal basis in April, June, August, and October in 2012 and January and April in 2013. St. 1 was changed to St. 2A after April 2012 because of logistical problems. Both stations have similar environmental conditions and are at a relatively close distance. Using a $5 \mathrm{~L}$ Niskin (General Oceanics Inc., Miami, FL, USA) water sampler, water samples were collected at different depths of three light intensities 
(100, 30, and $1 \%$ of surface irradiances; hereafter three light depths) and transferred to brown sample bottles, which were previously washed with a solution of $0.1 \mathrm{~N} \mathrm{HCl}$. The water samplings were conducted at high tide periods before noon. The three different light depths were determined by a Secchi disk using a vertical attenuation coefficient $\left(K_{\mathrm{d}}=1.7 /\right.$ Secchi depth) from Poole and Atkins (1929), which has been applied globally.

To obtain the in situ physical parameters, the water temperature and salinity were measured with a YSI-30 (YSI Incorporated, Yellow Springs, OH, USA), and photosynthetically active radiation (PAR) was measured onboard during the cruise. PAR was measured one time per cruise every $30 \mathrm{~s}$ during the incubation hours for primary productivity by a quantum sensor (LI-190SA; LI-COR Biosciences, Lincoln, NE, USA) with a data logger (LI-1400; LI-COR) on deck. Since the main purpose of the PAR measurements was to calculate the hourly primary productivity executed for $4-5 \mathrm{~h}$ during the day at around noon local time, the irradiance values in this study might not be representative for our sampling periods. Rainfall and river input data during the study period were obtained from the Korea Meteorological Administration (http://www.kma.go.kr/index.jsp) and the National Institute of Environmental Research (http://water.nier.go.kr/main/ mainContent.do). For the relationships between river input and other factors, river inputs were integrated from 20 days prior to our sampling dates since phytoplankton productivity is recovered 20 days after rainfall in Gwangyang Bay, according to Min et al. (2011).

\subsection{Chl $a$ and major inorganic nutrient analysis}

In order to determine $\mathrm{Chl} a$ concentration, water samples from three light depths were filtered through $25 \mathrm{~mm} \mathrm{GF} / \mathrm{F}$ (Whatman, Maidstone, UK; $0.7 \mu \mathrm{m}$ ), which were frozen immediately and returned to the laboratory at Pusan National University in Korea for further analysis. The filters for $\mathrm{Chl} a$ concentration were extracted in $90 \%$ acetone in a refrigerator $\left(4{ }^{\circ} \mathrm{C}\right)$ for $24 \mathrm{~h}$ and centrifuged for $20 \mathrm{~min}$ at $4000 \mathrm{rpm}$. Using a fluorometer (Turner Designs, San Jose, CA, USA; 10-AU), which had been calibrated with commercially purified Chl $a$ preparations, the $\mathrm{Chl} a$ concentrations were measured and calculated (Parsons et al., 1984). The water samples for inorganic nutrient concentrations from the surface and bottom waters were obtained from Niskin bottles. The samples were kept frozen $\left(-70^{\circ} \mathrm{C}\right)$ and sent for analysis to the laboratory at the East Sea Fisheries Research Institute (QuAAtro; Seal Analytical, South Hampton, UK).

\subsection{Particulate organic carbon and nitrogen analysis}

The water samples $(300 \mathrm{~mL})$ for POC, PON, and $\delta^{13} \mathrm{C}$ of POM were collected from the surface at the three stations during every sampling time. The water samples were filtered through pre-combusted $\left(450^{\circ} \mathrm{C}, 4 \mathrm{~h}\right) 25 \mathrm{~mm} \mathrm{GF} / \mathrm{F}$ (What- man; $0.7 \mu \mathrm{m}$ ) using a low vacuum pressure less than $100 \mathrm{~mm}$ $\mathrm{Hg}$. The filters for POC, PON, and $\delta^{13} \mathrm{C}$ values were preserved frozen $\left(-20^{\circ} \mathrm{C}\right)$ for further analysis at the home laboratory. For stable isotope analysis, the preserved filters were acidified with concentrated hydrochloric acid fumes overnight to remove carbonate (Hama et al., 1983), and the abundances of ${ }^{13} \mathrm{C}$ and ${ }^{15} \mathrm{~N}$ and the total amounts of POC and PON were determined using a Finnigan DELTAplus XP (Thermo Fisher Scientific, Waltham, MA, USA) mass spectrometer at the stable isotope laboratory of the University of Alaska Fairbanks, USA.

\subsection{Biochemical composition analysis}

The water samples for the biochemical composition (carbohydrates, proteins, and lipids) of POM were collected from three light depths. The water samples were filtered through $47 \mathrm{~mm} \mathrm{GF} / \mathrm{F}$ (Whatman; $0.7 \mu \mathrm{m}$ ), which were immediately frozen at $-70^{\circ} \mathrm{C}$ and preserved for biochemical composition analysis at the home laboratory.

\subsubsection{Protein analysis}

The protein (PRT) concentrations were assessed according to a modified method of that used by Lowry et al. (1951). The filters for the PRT analysis were transferred into $12 \mathrm{~mL}$ centrifuge tubes with $1 \mathrm{~mL} \mathrm{DH}_{2} \mathrm{O}$. The filters were grounded (using a glass rod) in the tubes with a $5 \mathrm{~mL}$ alkaline copper solution (a mixture of $2 \% \mathrm{Na}_{2} \mathrm{CO}_{3}$ in $0.1 \mathrm{~N} \mathrm{NaOH}$ with $0.5 \% \mathrm{CuSO}_{4} \cdot 5 \mathrm{H}_{2} \mathrm{O}$ in $1 \%$ sodium or potassium tartrate; $50: 1, v / v)$. The solutions for the PRT concentrations were mixed well (using a vortex) and allowed to stand for $10 \mathrm{~min}$ at room temperature in the hood. After $10 \mathrm{~min}, 0.5 \mathrm{~mL}$ of diluted Folin-Ciocalteu phenol reagent $(1: 1, v / v)$ was added to the solution, mixed occasionally with a vortex mixer, and allowed to sit for $1 \mathrm{~h} 30 \mathrm{~min}$. The solutions with a blue color were centrifuged at $3000 \mathrm{rpm}$ for $10 \mathrm{~min}$. The absorbance of the supernatant was measured at $750 \mathrm{~nm}$. Bovine serum albu$\min \left(2 \mathrm{mg} \mathrm{mL}^{-1}\right.$; Sigma-Aldrich, St. Louis, MO, USA) was used as a standard for the PRT concentration.

\subsubsection{Lipid analysis}

The lipid (LIP) concentrations were extracted according to a column method modified from Bligh and Dyer (1959) and Marsh and Weinstein (1966). The filters for LIP analysis were transferred into $16 \mathrm{~mL}$ glass tubes with $3 \mathrm{~mL}$ of chloroform-methanol $(1: 2, v / v)$. The filters in the tubes were grounded, and then the mixtures were mixed using a vortex mixer. For LIP extraction, glass tubes with samples were stored in the refrigerator $\left(4^{\circ} \mathrm{C}\right)$ to prevent the solvents from evaporating. After $1 \mathrm{~h}$, the solvents were centrifuged at $2000 \mathrm{rpm}$ for $10 \mathrm{~min}$ and the supernatants were collected and stored in new tubes. This extraction procedure was immediately performed once again. When the extractions were completed, $4 \mathrm{~mL}$ of $\mathrm{DH}_{2} \mathrm{O}$ was added to the solution in the 
Table 1. The environmental factors and Chl $a$ concentrations in Gwangyang Bay during the research period (“-” indicates no data).

\begin{tabular}{|c|c|c|c|c|c|c|c|c|c|c|c|c|}
\hline Year & Date & $\begin{array}{r}\text { Irradiance } \\
\left(\mu \mathrm{mols} \mathrm{m}^{-2} \mathrm{~s}^{-1}\right)\end{array}$ & Station & $\begin{array}{r}\text { Light } \\
\text { depth }(\%)\end{array}$ & $\begin{array}{r}\text { Temperature } \\
\left({ }^{\circ} \mathrm{C}\right)\end{array}$ & $\begin{array}{r}\text { Salinity } \\
(\% o)\end{array}$ & $\begin{array}{r}\text { Depth } \\
(\mathrm{m})\end{array}$ & $\begin{array}{l}\mathrm{NH}_{4} \\
(\mu \mathrm{M})\end{array}$ & $\begin{array}{r}\mathrm{NO}_{2}+\mathrm{NO}_{3} \\
(\mu \mathrm{M})\end{array}$ & $\begin{array}{l}\mathrm{SiO}_{2} \\
(\mu \mathrm{M})\end{array}$ & $\begin{array}{r}\mathrm{PO}_{4} \\
(\mu \mathrm{M})\end{array}$ & $\begin{array}{r}\text { Chl } a \\
\left(\mu g \mathrm{~L}^{-1}\right)\end{array}$ \\
\hline \multirow[t]{30}{*}{2012} & \multirow[t]{9}{*}{ April } & \multirow{9}{*}{$\begin{array}{r}167.9 \pm 133.5 \\
(\text { average } \pm S D)\end{array}$} & \multirow[t]{3}{*}{ St. 1} & 100 & 13.9 & 14.5 & 0 & 3.6 & 56.4 & 26.0 & 80.9 & 1.89 \\
\hline & & & & 30 & 13.3 & 25.6 & 1 & - & - & - & - & 1.95 \\
\hline & & & & 1 & 13.5 & 28.0 & 3 & 2.4 & 16.0 & 9.8 & 0.2 & 2.08 \\
\hline & & & \multirow[t]{3}{*}{ St. 4} & 100 & 15.0 & 24.4 & 0 & 2.6 & 15.1 & 16.3 & 0.2 & 1.81 \\
\hline & & & & 30 & 13.6 & 31.4 & 1 & - & - & - & - & - \\
\hline & & & & 1 & 12.3 & 32.9 & 5 & 1.9 & 2.1 & 2.1 & 0.1 & 2.03 \\
\hline & & & \multirow[t]{3}{*}{ St. 5} & 100 & 12.6 & 31.7 & 0 & 3.1 & 9.5 & 7.1 & 0.3 & 2.07 \\
\hline & & & & 30 & 12.3 & 31.6 & 1 & - & - & - & - & - \\
\hline & & & & 1 & 12.2 & 32.4 & 5 & 3.0 & 6.4 & 5.1 & 0.3 & 2.04 \\
\hline & \multirow[t]{6}{*}{ June } & \multirow[t]{6}{*}{$1158.1 \pm 627.6$} & \multirow[t]{3}{*}{ St. 2A } & 100 & 22.9 & 27.6 & 0 & - & - & - & - & 1.77 \\
\hline & & & & 30 & 22.8 & 27.6 & 1 & - & - & - & - & 0.76 \\
\hline & & & & 1 & 22.9 & 28.7 & 3 & - & - & - & - & 0.76 \\
\hline & & & \multirow[t]{3}{*}{ St. 4} & 100 & 23.6 & 31.5 & 0 & - & - & - & - & 1.00 \\
\hline & & & & 30 & 22.6 & 31.9 & 3 & - & - & - & - & 1.67 \\
\hline & & & & 1 & 22.1 & 32.3 & 11 & - & - & - & - & 1.02 \\
\hline & \multirow[t]{6}{*}{ August } & \multirow[t]{15}{*}{$1320.0 \pm 316.9$} & \multirow[t]{3}{*}{ St. 4} & 100 & 25.8 & 30.6 & 0 & 0.1 & 0.1 & 10.6 & 0.1 & 8.11 \\
\hline & & & & 30 & 25.7 & 31.6 & 2 & - & - & - & - & 8.49 \\
\hline & & & & 1 & 25.7 & 31.7 & 8 & 0.1 & 0.1 & 11.9 & 0.1 & 5.99 \\
\hline & & & \multirow[t]{3}{*}{ St. 5} & 100 & 25.6 & 31.6 & 0 & 0.7 & 0.3 & 8.2 & 0.0 & 14.20 \\
\hline & & & & 30 & 26.1 & 31.5 & 2 & - & - & - & - & 9.85 \\
\hline & & & & 1 & 25.7 & 31.7 & 8 & 0.1 & 0.1 & 10.1 & 0.1 & 3.19 \\
\hline & \multirow{9}{*}{ October } & & \multirow[t]{3}{*}{ St. 2A } & 100 & 20.6 & 29.8 & 0 & 1.4 & 3.0 & 11.3 & 0.1 & 1.07 \\
\hline & & & & 30 & 20.5 & 29.8 & 1 & - & - & - & - & 1.30 \\
\hline & & & & 1 & 21.9 & 30.2 & 3 & 1.3 & 1.3 & 8.1 & 0.1 & 1.24 \\
\hline & & & \multirow{3}{*}{ St. 4} & 100 & 20.9 & 30.3 & 0 & 1.6 & 3.1 & 14.0 & 0.1 & 2.69 \\
\hline & & & & 30 & 20.7 & 30.3 & 1 & - & - & - & - & 2.93 \\
\hline & & & & 1 & 20.6 & 30.6 & 5 & 1.1 & 0.6 & 7.4 & 0.1 & 1.74 \\
\hline & & & \multirow[t]{3}{*}{ St. 5} & 100 & 19.1 & 30.4 & 0 & 1.0 & 0.4 & 6.5 & 0.1 & 2.47 \\
\hline & & & & 30 & 18.5 & 30.5 & 2 & - & - & - & - & 1.98 \\
\hline & & & & 1 & 18.1 & 30.4 & 8 & 1.2 & 0.2 & 5.3 & 0.0 & 2.20 \\
\hline 2013 & January & $297.4 \pm 310.5$ & St. 2A & 100 & 5.5 & 20.5 & 0 & 0.5 & 4.2 & 4.0 & 0.1 & 1.39 \\
\hline & & & & 30 & 7.0 & 28.0 & 1 & - & - & - & - & 1.52 \\
\hline & & & & 1 & 7.3 & 29.4 & 4 & 0.5 & 3.7 & 3.6 & 0.1 & 1.48 \\
\hline & & & St. 4 & 100 & 7.7 & 31.1 & 0 & 1.0 & 3.8 & 3.4 & 0.1 & 2.79 \\
\hline & & & & 30 & 7.4 & 31.3 & 4 & - & - & - & - & 3.41 \\
\hline & & & & 1 & 7.3 & 32.8 & 12 & 0.6 & 3.1 & 2.5 & 0.0 & 5.37 \\
\hline & & & St. 5 & 100 & 6.3 & 31.8 & 0 & 0.8 & 3.3 & 2.6 & 0.1 & 5.79 \\
\hline & & & & 30 & 6.6 & 31.9 & 3 & - & - & - & - & 5.25 \\
\hline & & & & 1 & 6.4 & 32.5 & 11 & 1.0 & 3.0 & 3.6 & 0.2 & 5.33 \\
\hline & April & $1593.3 \pm 414.5$ & St. 2A & 100 & 14.3 & 26.2 & 0 & 1.9 & 3.7 & 3.1 & 0.1 & 1.81 \\
\hline & & & & 30 & 14.4 & 27.5 & 1 & - & - & - & - & 1.72 \\
\hline & & & & 1 & 14.3 & 29.1 & 3 & 1.5 & 2.5 & 2.3 & 0.1 & 2.06 \\
\hline & & & St. 4 & 100 & 14.7 & 32.0 & 0 & 1.6 & 2.0 & 2.5 & 0.1 & 2.24 \\
\hline & & & & 30 & 15.3 & 32.0 & 1 & - & - & - & - & 4.41 \\
\hline & & & & 1 & 15.2 & 32.6 & 5 & 1.5 & 1.7 & 1.6 & 0.1 & 7.39 \\
\hline & & & St. 5 & 100 & 16.1 & 31.9 & 0 & 1.1 & 1.3 & 1.3 & 0.1 & 4.39 \\
\hline & & & & 30 & 16.1 & 32.0 & 3 & - & - & - & - & 5.22 \\
\hline & & & & 1 & 16.6 & 32.3 & 11 & 1.1 & 0.7 & 1.0 & 0.1 & 5.90 \\
\hline
\end{tabular}

new tubes, and the solution was homogenized using a vortex mixer. After mixing, the tubes were centrifuged at $2000 \mathrm{rpm}$ for $10 \mathrm{~min}$, and the solvents were separated into two phases (the chloroform phase for lipids and the methanol $+\mathrm{DH}_{2} \mathrm{O}$ phase). The methanol $+\mathrm{DH}_{2} \mathrm{O}$ phase was removed from the solvent using a Pasteur pipette. The chloroform phase was placed in a dry oven at $40^{\circ} \mathrm{C}$ for $48 \mathrm{~h}$. After it totally dried for carbonization analysis (Marsh and Weinstein, 1966), $2 \mathrm{~mL}$ of $\mathrm{H}_{2} \mathrm{SO}_{4}$ was added to the tubes, and they were placed in a heating block at $200{ }^{\circ} \mathrm{C}$ for $15 \mathrm{~min}$. After this heating procedure, the tubes were quickly placed in a water bath at room temperature; $3 \mathrm{~mL}$ of $\mathrm{DH}_{2} \mathrm{O}$ was added to the tubes and the solvents were homogenized (with a vortex mixer) and stood for $10 \mathrm{~min}$ or until all bubbles had disappeared. The absorbance of the supernatant was measured at $375 \mathrm{~nm}$. 


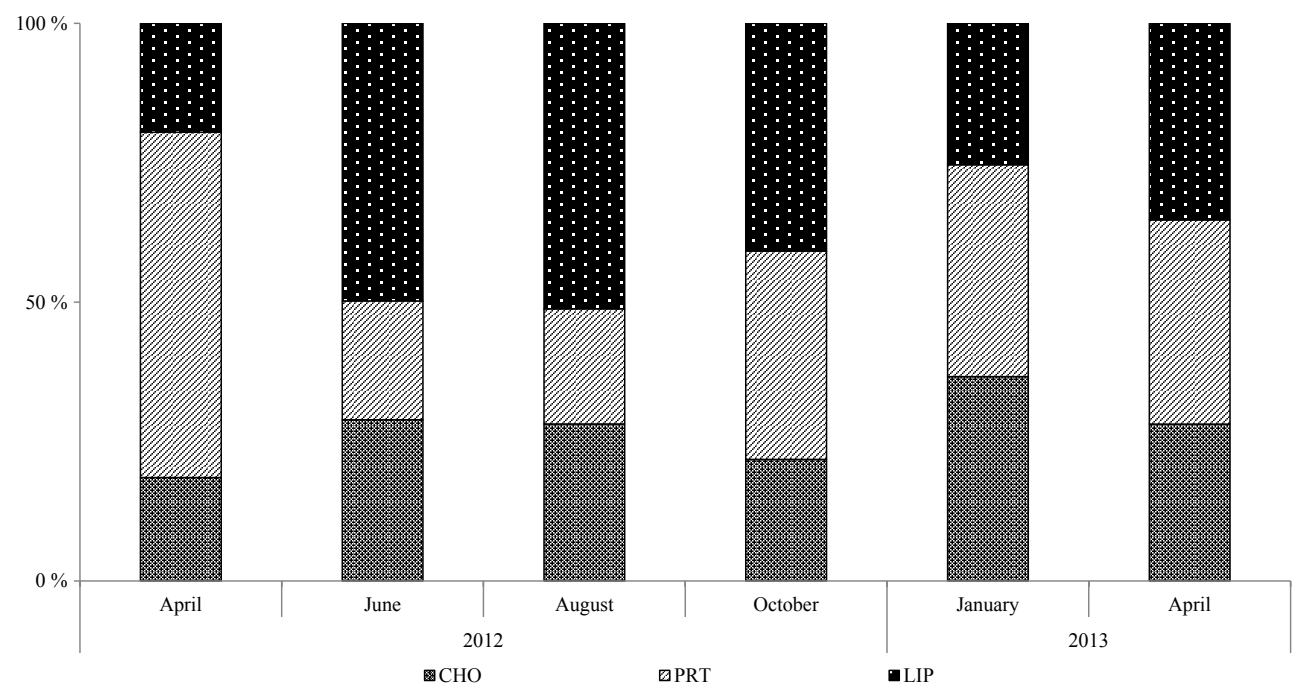

Figure 2. The seasonal variation in biochemical composition in Gwangyang Bay.

Tripalmitin solutions were used as a standard for the LIP concentration.

\subsubsection{Carbohydrate analysis}

Carbohydrate (CHO) concentrations were measured according to Dubois et al. (1956). The POM samples for carbohydrate analysis were transferred individually into $15 \mathrm{~mL}$ polypropylene (PP) tubes. After $1 \mathrm{~mL}$ of $\mathrm{DH}_{2} \mathrm{O}$ was added to the PP tubes, the samples were grounded using a glass rod; $1 \mathrm{~mL}$ of $5 \%$ phenol was additionally added for $\mathrm{CHO}$ extraction, and the solutions were allowed to stand for $40 \mathrm{~min}$ at room temperature in the hood. After the extraction, $5 \mathrm{~mL}$ of sulfuric acid $\left(\mathrm{H}_{2} \mathrm{SO}_{4}\right)$ was added to the solutions, mixed using a vortex mixer, and allowed to stand for $10 \mathrm{~min}$. The solutions with an orange-yellow color were centrifuged at $3500 \mathrm{rpm}$ for $10 \mathrm{~min}$. The absorbance of the supernatant was measured at $490 \mathrm{~nm}$ using UV spectrophotometer (Labomed Inc., Los Angeles, CA, USA). D (+) - glucose solutions $\left(1 \mathrm{mg} \mathrm{mL}^{-1}\right.$; Sigma-Aldrich) were used as a standard for the CHO concentration.

\subsection{Statistical analyses and calorific value calculation}

Statistical tests were carried out using the statistic software SPSS ( $t$ test, ANOVA and Pearson's correlation coefficient). The level of significance was set at $p<0.05$. The calorific value $\left(\mathrm{Kcal} \mathrm{g}^{-1}\right)$ of the food material (FM) (FM was defined by Danovaro et al., 2000; PRT + LIP + CHO concentrations; hereafter FM) and the calorific content of $\mathrm{FM}\left(\mathrm{Kcal} \mathrm{m}^{-3}=\mathrm{Kcal} \mathrm{g}^{-1} \times \mathrm{g} \mathrm{FM} \mathrm{m}^{-3}\right)$ were calculated using the Winberg (1971) equation $\left(\mathrm{Kcal} \mathrm{g}^{-1}=0.055 \%\right.$ proteins $+0.041 \%$ carbohydrates $+0.095 \%$ lipids).

\section{Results}

\subsection{Seasonal distribution and variation in environmental factors and $\mathrm{Chl} a$ concentrations}

The values of the environmental factors were summarized in Table 1. The temperature ranged from 5.5 to $26.1^{\circ} \mathrm{C}$, and the salinity ranged from 14.5 to $32.9 \%$ o during our sampling period. Relatively lower salinity, which is mainly affected by the freshwater input from the Seomjin River, was observed at St. 2A. The annual average euphotic depth was $6.5 \pm 3.4 \mathrm{~m}$, ranging from 2 to $12 \mathrm{~m}$.

The highest nutrient concentrations were measured in April 2012 when the concentrations of $\mathrm{NO}_{2}+\mathrm{NO}_{3}, \mathrm{SiO}_{2}$, $\mathrm{NH}_{4}$, and $\mathrm{PO}_{4}$ were above 5.0, 2.0, and $0.2 \mu \mathrm{M}$, respectively, except at $1 \%$ light depth at St. 4. All inorganic nutrients except $\mathrm{SiO}_{2}$ were nearly depleted in August 2012 (Table 1). During the rest of our study period, $\mathrm{NO}_{2}+\mathrm{NO}_{3}$ and $\mathrm{SiO}_{2}$ concentrations were observed with similar decreasing patterns from St. 1 or St. 2 A to St. 5 . $\mathrm{NH}_{4}$ concentrations averaged from October 2012 to April 2013 were $1.1 \pm 0.4 \mu \mathrm{M}$, ranging from 0.5 to $1.9 \mu \mathrm{M}$. $\mathrm{PO}_{4}$ concentrations (average $\pm \mathrm{SD}=0.1 \pm 0.1 \mu \mathrm{M}$ ) ranged from 0 to $0.4 \mu \mathrm{M}$ during the study period. To determine the nutrient conditions, the nutrient concentrations and their molar ratios in this study were summarized in Table 2. The ranges of the molar ratios from April 2012 to April 2013 were 9.8-69.5, 15.5-173.4, and 0.6-42.7 for DIN : DIP, DSi : DIP, and DSi : DIN, respectively (Table 2).

The surface irradiance averaged from each measurement for $4-5 \mathrm{~h}$ ranged from $167.9 \pm 133.5$ to $1593.3 \pm 414.5 \mu \mathrm{mols} \mathrm{m}^{-2} \mathrm{~s}^{-1} \quad$ (average $\pm \mathrm{SD}$ ) from April 2012 to April 2013. The highest and lowest irradiances were recorded in April 2013 and April 2012, respectively. Chl $a$ concentrations in the euphotic depth 
Table 2. The observed nutrient limitations during the study period (nd: not detected).

\begin{tabular}{|c|c|c|c|c|c|c|c|c|c|}
\hline \multirow[b]{2}{*}{ Year } & \multirow[b]{2}{*}{ Date } & \multicolumn{4}{|c|}{ Based on absolute concentrations $(\mu \mathrm{M})$} & \multicolumn{4}{|c|}{ Based on molar ratios } \\
\hline & & DIN & $\mathrm{SiO}_{2}$ & $\mathrm{PO}_{4}$ & Limitation & DIN : DIP & DSi : DIP & DSi : DIN & Limitation \\
\hline \multirow[t]{4}{*}{2012} & April & $20.3 \pm 20.2$ & $11.1 \pm 8.8$ & $13.6 \pm 32.9$ & nd & $56.8 \pm 45.5$ & $37.5 \pm 36.9$ & $0.6 \pm 0.2$ & $\mathrm{P}$ \\
\hline & June & - & - & - & - & - & - & - & - \\
\hline & August & $0.4 \pm 0.4$ & $10.2 \pm 1.5$ & $0.1 \pm 0.0$ & $\mathrm{~N}, \mathrm{P}$ & $9.8 \pm 14.2$ & $173.4 \pm 56.5$ & $42.7 \pm 23.7$ & $\mathrm{~N}$ \\
\hline & October & $2.7 \pm 1.5$ & $8.8 \pm 3.3$ & $0.1 \pm 0.0$ & $\mathrm{P}$ & $40.4 \pm 20.8$ & $142.2 \pm 74.0$ & $3.6 \pm 0.8$ & $\mathrm{P}$ \\
\hline \multirow[t]{2}{*}{2013} & January & $4.2 \pm 0.4$ & $3.3 \pm 0.6$ & $0.1 \pm 0.1$ & $\mathrm{P}$ & $69.5 \pm 63.1$ & $50.6 \pm 41.4$ & $0.8 \pm 0.1$ & $\mathrm{P}$ \\
\hline & April & $3.4 \pm 1.3$ & $2.0 \pm 0.8$ & $0.1 \pm 0.0$ & $\mathrm{Si}, \mathrm{P}$ & $27.1 \pm 8.9$ & $15.5 \pm 5.5$ & $0.6 \pm 0.1$ & nd \\
\hline
\end{tabular}

Table 3. The monthly patterns of rainfall and river input.

\begin{tabular}{llrr}
\hline Year & Date & $\begin{array}{r}\text { Rainfall } \\
(\mathrm{mm})\end{array}$ & $\begin{array}{r}\text { River input } \\
\left(10^{6} \mathrm{t}\right)\end{array}$ \\
\hline \multirow{2}{2}{012} & April & 195.5 & 149.4 \\
& May & 44.4 & 148.9 \\
& June & 69.6 & 42.3 \\
& July & 235.8 & 223.3 \\
& August & 559.0 & 228.9 \\
& September & 360.1 & 447.2 \\
& October & 38.0 & 98.5 \\
& November & 52.5 & 83.4 \\
& December & 96.7 & 89.4 \\
\hline \multirow{2}{*}{2013} & January & 15.6 & 79.3 \\
& February & 116.4 & 94.6 \\
& March & 79.9 & 91.5 \\
& April & 99.1 & 100.3 \\
\hline
\end{tabular}

ranged from 0.8 to $14.2 \mu \mathrm{g} \mathrm{L}^{-1}$ during the study period (annual average $\pm \mathrm{SD}=3.4 \pm 2.8 \mu \mathrm{g} \mathrm{L}^{-1}$; Table 1).

The monthly rainfall and river input at the study location ranged from 15.6 to $559.0 \mathrm{~mm}$ (annual average $\pm \mathrm{SD}=151.0 \pm 155.5 \mathrm{~mm})$ and 42.3 to $447.2 \times 10^{6} \mathrm{t}$ (annual average $=144.4 \times 10^{6} \mathrm{t}$ ), respectively (Table 3 ). The rainfall and river input were recorded as high during summer and low during winter.

\section{$3.2 \delta^{13} \mathrm{C}$ values and carbon to nitrogen ratios of $\mathrm{POM}$}

The $\delta^{13} \mathrm{C}$ values of the sea surface POM ranged from -23.1 to $-16.5 \%$ and the annual average $\delta^{13} \mathrm{C}$ value was $-20.9 \%$ ( $\mathrm{SD}= \pm 3.2 \%$ ). The annual average carbon to nitrogen $(\mathrm{C}: \mathrm{N})$ ratio of $\mathrm{POM}$ was $7.0 \pm 0.4$ (average $\pm \mathrm{SD})$, ranging from 6.8 to 7.7 (Table 4 ).

\subsection{Seasonal variation in biochemical composition}

The contents of CHO, PRT, and LIP of POM in the water column were $14.2-412.3 \mu \mathrm{g} \mathrm{L}^{-1}\left(129.5 \pm 87.2 \mu \mathrm{g} \mathrm{L}^{-1}\right), 22.8-$ $382.4 \mu \mathrm{g} \mathrm{L}^{-1}\left(155.0 \pm 73.3 \mu \mathrm{g} \mathrm{L}^{-1}\right)$, and $21.4-401.4 \mu \mathrm{g} \mathrm{L}^{-1}$ $\left(154.9 \pm 78.9 \mu \mathrm{g} \mathrm{L}^{-1}\right)$, respectively (Table 4). The FM
Table 4. The $\delta^{13} \mathrm{C}$ values and $\mathrm{C}: \mathrm{N}$ ratios of POM at the surface in Gwangyang Bay.

\begin{tabular}{llrr}
\hline Year & Date & $\begin{array}{r}\delta^{13} \mathrm{C} \\
(\% o)\end{array}$ & $\begin{array}{r}\mathrm{C}: \mathrm{N} \\
(\text { molar }: \text { molar })\end{array}$ \\
\hline \multirow{2}{2}{012} & April & $-22.8 \pm 2.9$ & $7.0 \pm 1.2$ \\
& June & $-23.1 \pm 1.3$ & $6.8 \pm 0.2$ \\
& August & $-16.5 \pm 2.4$ & $6.7 \pm 0.5$ \\
& October & $-17.1 \pm 0.9$ & $6.9 \pm 0.6$ \\
\hline \multirow{2}{*}{2013} & January & $-22.5 \pm 0.6$ & $7.7 \pm 0.6$ \\
& April & $-23.1 \pm 0.2$ & $6.8 \pm 0.7$ \\
& (average $\pm \mathrm{SD})$ & $-20.9 \pm 3.2$ & $7.0 \pm 0.4$ \\
\hline
\end{tabular}

contents of POM ranged from 170.9 to $915.7 \mu \mathrm{g} \mathrm{L}^{-1}$ $\left(435.5 \pm 175.5 \mu \mathrm{g} \mathrm{L}^{-1}\right)$. On a monthly basis, we averaged each biochemical compound and FM from all depths and stations (Fig. 2). The biochemical compositions varied seasonally. The CHO and LIP concentrations increased from April to August and decreased from August to October in 2012. In contrast, the PRT concentrations decreased from April to October in 2012 and increased from October in 2012 to April in 2013. The seasonal pattern of FM concentrations was similar to the pattern of Chl $a$ concentrations $(r=-0.36, p<0.05$; Pearson's correlation coefficient).

In order to estimate the biochemical composition as food quality, we obtained the relative contributions of each biochemical concentration of POM to FM based on percentage. The biochemical compositions of each class (CHO, PRT, and LIP) were 8.3-59.1, 6.8-74.9, and 9.4-68.3\%, respectively (annual average \pm SD of CHO, PRT, and LIP composition $=26.4 \pm 9.4,37.8 \pm 16.1$, and $35.7 \pm 13.9 \%$, respectively; Table 5).

\subsection{Seasonal variations in the calorific values and contents of FM}

The calorific values and contents of FM were 5.4-7.9 $\mathrm{Kcal} \mathrm{g}^{-1} \quad$ (annual $\quad$ average $\pm \mathrm{SD}=6.6 \pm 0.6$ $\mathrm{Kcal} \mathrm{g}^{-1}$ ) and $1.0-6.1 \mathrm{Kcal} \mathrm{m}^{-3}$ (annual average $\pm \mathrm{SD}=2.8 \pm 1.1 \mathrm{Kcal} \mathrm{m}^{-3}$ ), respectively (Table 5). 
Table 5. The biochemical concentrations, composition, calorific values, and contents in Gwangyang Bay (“-” indicates no data).

\begin{tabular}{|c|c|c|c|c|c|c|c|c|c|c|c|c|}
\hline Year & Date & Station & $\begin{array}{r}\text { Light } \\
\text { depth }(\%)\end{array}$ & $\begin{array}{r}\mathrm{CHO} \\
\left(\mu \mathrm{g} \mathrm{L}^{-1}\right)\end{array}$ & $\begin{array}{r}\text { PRT } \\
\left(\mu \mathrm{gL}^{-1}\right)\end{array}$ & $\begin{array}{r}\text { LIP } \\
\left(\mu \mathrm{gL}^{-1}\right)\end{array}$ & $\begin{array}{r}\text { FM } \\
\left(\mu \mathrm{gL}^{-1}\right)\end{array}$ & $\begin{array}{r}\mathrm{CHO} / \mathrm{FM} \\
(\%)\end{array}$ & $\begin{array}{r}\text { PRT/FM } \\
(\%)\end{array}$ & $\begin{array}{r}\text { LIP/FM } \\
(\%)\end{array}$ & Kcal g $^{-1}$ & $\mathrm{Kcal} \mathrm{m}^{-3}$ \\
\hline \multirow{30}{*}{2012} & \multirow[t]{9}{*}{ April } & \multirow[t]{3}{*}{ St. 1} & 100 & 45.0 & 144.2 & 22.9 & 212.1 & 21.2 & 68.0 & 10.8 & 5.6 & 1.2 \\
\hline & & & 30 & 53.1 & 218.6 & 51.9 & 323.6 & 16.4 & 67.6 & 16.0 & 5.9 & 1.9 \\
\hline & & & 1 & 53.1 & 220.4 & 84.2 & 357.6 & 14.8 & 61.6 & 23.5 & 6.2 & 2.2 \\
\hline & & \multirow[t]{3}{*}{ St. 4} & 100 & 14.2 & 128.1 & 28.6 & 170.9 & 8.3 & 74.9 & 16.7 & 6.1 & 1.0 \\
\hline & & & 30 & 50.0 & 155.1 & 21.4 & 226.5 & 22.1 & 68.5 & 9.4 & 5.6 & 1.3 \\
\hline & & & 1 & 20.2 & 146.0 & 37.3 & 203.5 & 9.9 & 71.8 & 18.3 & 6.1 & 1.2 \\
\hline & & \multirow{3}{*}{ St. 5} & 100 & 60.2 & 198.0 & 143.0 & 401.2 & 15.0 & 49.3 & 35.7 & 6.7 & 2.7 \\
\hline & & & 30 & 132.4 & 198.0 & 42.8 & 373.2 & 35.5 & 53.1 & 11.5 & 5.5 & 2.0 \\
\hline & & & 1 & 146.7 & 265.3 & 210.0 & 622.1 & 23.6 & 42.7 & 33.8 & 6.5 & 4.1 \\
\hline & \multirow[t]{6}{*}{ June } & \multirow[t]{3}{*}{ St. 2A } & 100 & 170.7 & 99.7 & 233.5 & 503.8 & 33.9 & 19.8 & 46.3 & 6.9 & 3.5 \\
\hline & & & 30 & 135.5 & 108.0 & 251.9 & 495.4 & 27.3 & 21.8 & 50.9 & 7.2 & 3.5 \\
\hline & & & 1 & 163.5 & 85.0 & 225.1 & 473.7 & 34.5 & 17.9 & 47.5 & 6.9 & 3.3 \\
\hline & & \multirow[t]{3}{*}{ St. 4} & 100 & 99.1 & 44.6 & 199.5 & 343.2 & 28.9 & 13.0 & 58.1 & 7.4 & 2.5 \\
\hline & & & 30 & 133.4 & 142.4 & 203.5 & 479.3 & 27.8 & 29.7 & 42.4 & 6.8 & 3.3 \\
\hline & & & 1 & 91.6 & 110.8 & 232.3 & 434.6 & 21.1 & 25.5 & 53.5 & 7.3 & 3.2 \\
\hline & \multirow[t]{6}{*}{ August } & \multirow[t]{3}{*}{ St. 4} & 100 & 69.3 & 73.9 & 213.5 & 356.7 & 19.4 & 20.7 & 59.9 & 7.6 & 2.7 \\
\hline & & & 30 & 61.2 & 56.5 & 173.8 & 291.5 & 21.0 & 19.4 & 59.6 & 7.6 & 2.2 \\
\hline & & & 1 & 127.2 & 77.9 & 162.2 & 367.3 & 34.6 & 21.2 & 44.2 & 6.8 & 2.5 \\
\hline & & \multirow[t]{3}{*}{ St. 5} & 100 & 155.5 & 289.4 & 204.7 & 649.6 & 23.9 & 44.6 & 31.5 & 6.4 & 4.2 \\
\hline & & & 30 & 412.3 & 102.0 & 401.4 & 915.7 & 45.0 & 11.1 & 43.8 & 6.6 & 6.1 \\
\hline & & & 1 & 83.3 & 22.8 & 228.3 & 334.4 & 24.9 & 6.8 & 68.3 & 7.9 & 2.6 \\
\hline & \multirow[t]{9}{*}{ October } & \multirow[t]{3}{*}{ St. $2 \mathrm{~A}$} & 100 & 71.0 & 82.2 & 104.1 & 257.3 & 27.6 & 32.0 & 40.5 & 6.7 & 1.7 \\
\hline & & & 30 & 42.7 & 62.4 & 100.3 & 205.4 & 20.8 & 30.4 & 48.8 & 7.2 & 1.5 \\
\hline & & & 1 & 74.3 & 111.6 & 98.5 & 284.4 & 26.1 & 39.2 & 34.6 & 6.5 & 1.9 \\
\hline & & \multirow{3}{*}{ St. 4} & 100 & 51.6 & 105.2 & 105.3 & 262.2 & 19.7 & 40.1 & 40.2 & 6.8 & 1.8 \\
\hline & & & 30 & 119.4 & 121.9 & 144.4 & 385.6 & 31.0 & 31.6 & 37.4 & 6.6 & 2.5 \\
\hline & & & 1 & 78.5 & 169.0 & 134.4 & 381.9 & 20.6 & 44.2 & 35.2 & 6.6 & 2.5 \\
\hline & & \multirow[t]{3}{*}{ St. 5} & 100 & 37.2 & 70.0 & 86.5 & 193.6 & 19.2 & 36.1 & 44.7 & 7.0 & 1.4 \\
\hline & & & 30 & 42.3 & 92.5 & 112.0 & 246.7 & 17.2 & 37.5 & 45.4 & 7.1 & 1.7 \\
\hline & & & 1 & 33.9 & 108.4 & 97.3 & 239.7 & 14.2 & 45.2 & 40.6 & 6.9 & 1.7 \\
\hline \multirow[t]{18}{*}{2013} & \multirow[t]{9}{*}{ January } & \multirow[t]{3}{*}{ St. 2A } & 100 & 150.3 & 139.3 & 115.5 & 405.2 & 37.1 & 34.4 & 28.5 & 6.1 & 2.5 \\
\hline & & & 30 & 347.0 & 131.1 & 109.2 & 587.3 & 59.1 & 22.3 & 18.6 & 5.4 & 3.2 \\
\hline & & & 1 & 331.3 & 127.1 & - & - & - & - & - & - & 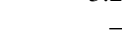 \\
\hline & & St. 4 & 100 & 171.6 & 164.0 & - & - & - & - & - & - & - \\
\hline & & & 30 & 183.5 & 168.7 & 139.7 & 491.9 & 37.3 & 34.3 & 28.4 & 6.1 & 3.0 \\
\hline & & & 1 & 115.9 & 182.3 & 107.1 & 405.2 & 28.6 & 45.0 & 26.4 & 6.2 & 2.5 \\
\hline & & St. 5 & 100 & 113.6 & 212.0 & 133.4 & 459.0 & 24.7 & 46.2 & 29.1 & 6.3 & 2.9 \\
\hline & & & 30 & 264.1 & 204.8 & 120.5 & 589.4 & 44.8 & 34.8 & 20.4 & 5.7 & 3.4 \\
\hline & & & 1 & 99.3 & 195.5 & 104.2 & 399.0 & 24.9 & 49.0 & 26.1 & 6.2 & 2.5 \\
\hline & Apirl & St. 2A & 100 & 237.7 & 262.9 & 189.9 & 690.5 & 34.4 & 38.1 & 27.5 & 6.1 & 4.2 \\
\hline & & & 30 & 185.5 & 308.0 & 198.7 & 692.3 & 26.8 & 44.5 & 28.7 & 6.3 & 4.3 \\
\hline & & & 1 & 274.8 & 382.4 & 180.3 & 837.5 & 32.8 & 45.7 & 21.5 & 5.9 & 4.9 \\
\hline & & St. 4 & 100 & 115.0 & 141.9 & 181.4 & 438.4 & 26.2 & 32.4 & 41.4 & 6.8 & 3.0 \\
\hline & & & 30 & 116.4 & 187.0 & 191.0 & 494.5 & 23.5 & 37.8 & 38.6 & 6.7 & 3.3 \\
\hline & & & 1 & 205.2 & 222.1 & 185.7 & 612.9 & 33.5 & 36.2 & 30.3 & 6.2 & 3.8 \\
\hline & & St. 5 & 100 & 160.4 & 176.3 & 289.1 & 625.7 & 25.6 & 28.2 & 46.2 & 7.0 & 4.4 \\
\hline & & & 30 & 146.9 & 217.8 & 253.3 & 618.0 & 23.8 & 35.2 & 41.0 & 6.8 & 4.2 \\
\hline & & & 1 & 171.3 & 204.9 & 272.6 & 648.8 & 26.4 & 31.6 & 42.0 & 6.8 & 4.4 \\
\hline
\end{tabular}

The calorific values had no apparent seasonal pattern, whereas the calorific contents had a seasonal pattern similar to the seasonal variation in FM concentrations.

\subsection{Relationship between biochemical pools and environmental conditions}

The relationships between the biochemical pools and environmental conditions were determined by using a Pearson's correlation matrix (Table 6). Based on the results, we found significant positive relationships between PRT composition and river input $(r=0.84, p<0.01$; Fig. 3) and PRT 


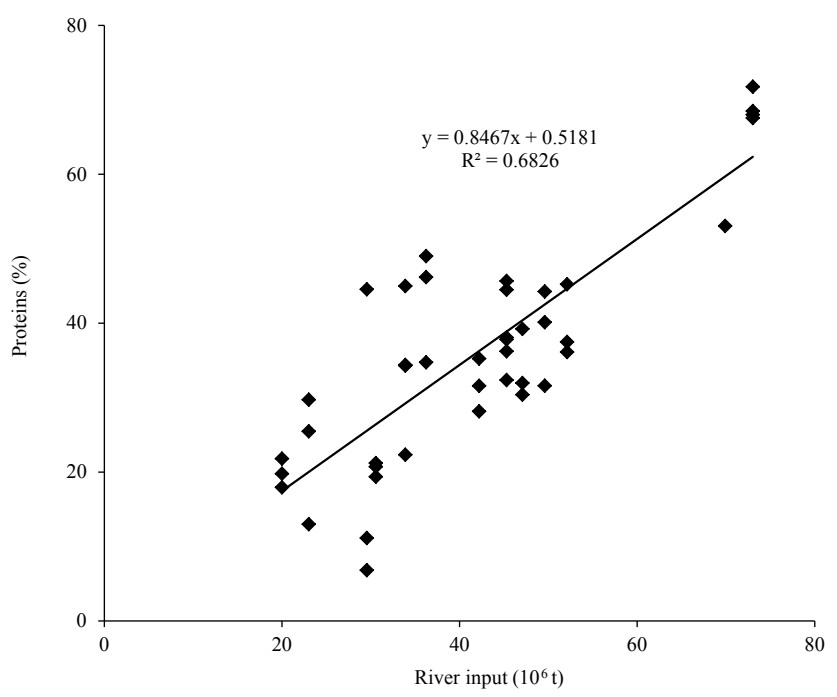

Figure 3. The positive relationship between river input and protein composition. River inputs were integrated from 20 days prior to our sampling dates.

Table 6. The significant correlation coefficient $(r)$ among proteins (PRT), lipids (LIP), and environmental factors (ns: no significance; **: $p<0.01)$. River inputs were integrated from 20 days prior to our sampling dates.

\begin{tabular}{|c|c|c|c|}
\hline Variables & $r$ & $p$ & $n$ \\
\hline$\%$ PRT $\times$ Temp & -0.52 & $* *$ & 46 \\
\hline$\%$ LIP $\times$ Temp & 0.72 & $* *$ & 46 \\
\hline$\% \mathrm{PRT} \times \mathrm{NH}_{4}$ & 0.69 & $* *$ & 28 \\
\hline$\% \mathrm{LIP} \times \mathrm{NH}_{4}$ & -0.59 & $* *$ & 28 \\
\hline$\% \mathrm{PRT} \times \mathrm{NO}_{2}+\mathrm{NO}_{3}$ & 0.54 & $* *$ & 28 \\
\hline$\% \mathrm{LIP} \times \mathrm{NO}_{2}+\mathrm{NO}_{3}$ & -0.53 & $* *$ & 28 \\
\hline$\%$ PRT $\times$ River input & 0.84 & $* *$ & 46 \\
\hline$\%$ LIP $\times$ River input & -0.63 & $* *$ & 46 \\
\hline $\mathrm{NH}_{4} \times$ River input & 0.91 & $* *$ & 28 \\
\hline $\mathrm{NO}_{2}+\mathrm{NO}_{3} \times$ River input & 0.55 & $* *$ & 28 \\
\hline$\% \mathrm{PRT} \times \% \mathrm{LIP}$ & -0.81 & $* *$ & 46 \\
\hline$\%$ PRT $\times$ Irradiance & -0.22 & ns & 39 \\
\hline$\%$ LIP $\times$ Irradiance & 0.24 & ns & 39 \\
\hline
\end{tabular}

composition and dissolved nitrogen concentrations $\left(\mathrm{NH}_{4}\right.$ : $\left.r=0.69, p<0.01 ; \mathrm{NO}_{2}+\mathrm{NO}_{3}: r=0.54, p<0.01\right)$. The lipid composition had inverse relationships with river input $(r=-0.63, p<0.01)$ and dissolved nitrogen concentrations $\left(\mathrm{NH}_{4}: r=-0.59, p<0.01 ; \mathrm{NO}_{2}+\mathrm{NO}_{3}: r=-0.53\right.$, $p<0.01)$. These relationships led to a significant reverse relationship between PRT composition and LIP composition $(r=-0.81, p<0.01$; Fig. 4$)$. The PRT composition was negatively correlated with temperature $(r=-0.52, p<$ 0.01 ), whereas the LIP composition was positively correlated with temperature $(r=0.72, p<0.01)$.

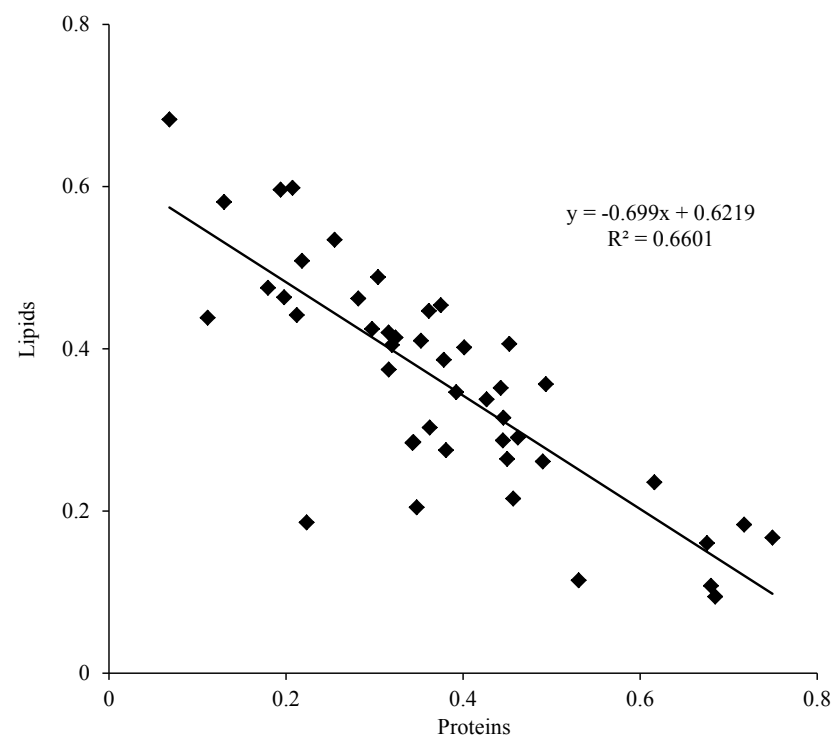

Figure 4. The inverse relationship between lipid compositions and protein compositions.

\section{Discussion and conclusion}

\subsection{Environmental conditions and Chl $a$ concentration}

The annual average $\mathrm{Chl} a$ concentration during the research period is in a similar range as the Chl $a$ concentrations reported previously in Gwangyang Bay, although it varied across different seasons and sampling depths (Cho et al., 1994; Choi and Noh, 1998; Lee et al., 2001a; Kwon et al., 2002; Jang et al., 2005; Yang et al., 2005; Baek et al., 2011, 2015; Min et al., 2011). Previous studies reported that the Chl $a$ concentration was influenced mainly by salinity, temperature, and nutrients (nitrate and phosphate) depending on freshwater input from the Seomjin River. Our results in this study were similar to former studies $(r=0.34$ and -0.41 , $p<0.05$, and $n=48$ and 28 for salinity and $\mathrm{NH}_{4}$ ). However, high Chl $a$ concentrations were previously recorded in spring and fall, whereas the highest concentrations were observed in summer (August 2012) in this study. In fact, Baek et al. (2015) similarly reported that high Chl $a$ concentrations were found in summer, although there was a difference between the environmental factors and $\mathrm{Chl} a$ concentrations compared with our results. The high levels of Chl $a$ were observed with high nutrient concentrations and low salinity levels in the surface water by Baek et al. (2015), whereas the high values existed with low nutrient concentrations and high salinity levels in our results.

Despite this dissimilarity in environmental factors with high Chl $a$ concentrations, we also found the highest Chl $a$ concentrations observed in summer. According to Shaha and Cho (2009), there is a tendency toward increasing precipitation and river input in Gwangyang Bay during summer. This trend could increase the loading nutrients from freshwater for 
maintaining phytoplankton growth in summer. In addition, a strong light intensity during summer could be favorable for phytoplankton growth, since our study area was subject to extremely turbid conditions during almost all seasons due to freshwater discharge and a strong spring-neap tidal oscillation. As a result, the combination of these factors is believed to enhance the Chl $a$ concentration and the primary production of phytoplankton during summer in Gwangyang Bay.

\subsection{POM characterization}

In general, POM consists of a mixture of living as well as detritus materials (phytoplankton, bacteria, zooplankton, fecal pellets, terrestrial matter, etc.) originating from freshwater and estuarine and marine environments. POM samples can be characterized or determined for the source of the major contributor(s). The $\mathrm{C}: \mathrm{N}$ ratio generally ranges between 6 and 10 for phytoplankton, whereas the ratios are between 3 and 6 for zooplankton and bacteria (Savoye et al., 2003; references therein). For terrestrial organic matter, the $\mathrm{C}: \mathrm{N}$ ratios are normally over 12 (Savoye et al., 2003; references therein). Therefore, it is useful to classify phytoplankton from heterotrophs and terrestrial materials (Lobbes et al., 2000; Savoye et al., 2003; Lee and Whitledge, 2005). In this study, the average $\mathrm{C}: \mathrm{N}$ ratio of $\mathrm{POM}$ was $7.0(\mathrm{SD}= \pm 0.4)$, which indicates that this POM is mainly phytoplankton (Table 4). However, the original $\mathrm{C}: \mathrm{N}$ ratio can be changed by biochemical alterations. For example, $\mathrm{PON}$ is preferentially degraded compared to the POC of phytoplankton, which causes an increase in the $\mathrm{C}: \mathrm{N}$ ratio (Thornton and McManus, 1994; Savoye et al., 2003). In contrast, terrestrial organic matter with high $\mathrm{C}: \mathrm{N}$ ratios colonized by bacteria with low $\mathrm{C}: \mathrm{N}$ ratios could lower their initially high $\mathrm{C}: \mathrm{N}$ ratio (Savoye et al., 2003; references therein). Therefore, similar $\mathrm{C}: \mathrm{N}$ ratios of POM could be produced by degraded phytoplankton and bacteria-colonized terrestrial organic matter (Lancelot and Billen, 1985; Savoye et al., 2003). In addition to $\mathrm{C}: \mathrm{N}$ ratios, the $\delta^{13} \mathrm{C}$ of $\mathrm{POM}$ can be alternatively used to determine origin. Kang et al. (2003) reported that the average $\delta^{13} \mathrm{C}$ signature of phytoplankton in Gwangyang Bay was $-20.8 \%$ o $(\mathrm{SD}= \pm 1.1 \%$ ). In this study, our average $\delta^{13} \mathrm{C}$ signature of $\mathrm{POM}$ was $-20.9 \%$ o $(\mathrm{SD}= \pm 3.2 \%$ ), which also indicates that POM was mostly phytoplankton during the study period (Table 4). However, some large contributions of benthic microalgae were seasonally found in our samples with relatively higher $\delta^{13} \mathrm{C}$ values in August and October 2012 (Table 4). According to Kang et al. (2003), the average $\delta^{13} \mathrm{C}$ value of benthic microalgae is approximately $-14.1 \%$ in Gwangyang Bay. Based on our $\mathrm{C}: \mathrm{N}$ ratio and the $\delta^{13} \mathrm{C}$ value in this study, we confirmed that our POM samples were primarily comprised of phytoplankton (seasonally benthic microalgae) in Gwangyang Bay. It is interesting that river-derived terrestrial organic matter was not an important component of the POM in Gwangyang Bay because there is a large amount of river runoff. Indeed, several previous stud- ies reported a small fraction of terrestrial particulate matter in the same bay as well as in the southeastern coastal bays in Korea (Kang et al., 1993; Lee et al., 2001b; Kwon et al., 2002). Currently, we do not have solid mechanisms to explain the low contribution of terrestrial organic matter. Further investigation is needed for this paradoxical process.

\subsection{Environmental conditions and biochemical pools}

The biochemical pools of POM originating from phytoplankton are influenced by various environmental factors, such as temperature, salinity, nutrients, and light conditions (Morris et al., 1974; Smith and Morris, 1980; Rivkin and Voytek, 1987; Boëchat and Giani, 2008; Cuhel and Lean, 1987; Mock and Kroon, 2002; Khotimchenko and Yakoleva, 2005; Ventura et al., 2008; Sterner et al., 1997). In this study, significant relationships were found between environmental conditions and biochemical pools, especially PRT and LIP (Table 5). Temperature was positively and negatively correlated with LIP and PRT. Previous studies reported that higher temperature stress mainly affects nitrogen metabolism (Kakinuma et al., 2006), which is related to a significant decrease in PRT with increases in LIP and CHO content (Tomaselli et al., 1988; Oliveira et al., 1999). In phytoplankton under high temperature-stressed conditions, the decrease in PRT content is related to the breakdown of the protein structure and interference with enzyme regulators (Pirt, 1975). LIP is predominant because LIP is more closely associated with the cell structure, particularly thickened cell walls (Smith et al., 1989; Kakinuma et al., 2001, 2006). Our results are in agreement with other work, as described above.

The relationships between nutrients and biochemical pools could be explained by nutrient limitation and the characteristics of each biochemical compound. A combination of nutrient concentrations and ratios can be used to assess nutrient limitation (Dortch and Whitledge, 1992; Justić et al., 1995). Dortch and Whitledge (1992) suggested that nutrient limitations exist in the Mississippi river plume and the Gulf of Mexico. This is based on the assumption that if the dissolved inorganic phosphorus (DIP), dissolved inorganic nitrogen (DIN), and dissolved silicon (DSi) concentrations in the water column are less than $0.2,1.0$, and $2.0 \mu \mathrm{M}$, respectively, depending on the half-saturation constant $\left(K_{\mathrm{S}}\right)$, then the threshold value is required for the uptake and growth of phytoplankton (Eppley et al., 1969; Fisher et al., 1988). In addition, the molar ratios of DIN : DIP, DSi : DIN, and DSi : DIP can be indicators of the nutritional status and the physiological behavior of phytoplankton (Redfield et al., 1963; Goldman et al., 1979; Elrifi and Turpin, 1985; Dortch and Whitledge 1992; Roelke et al., 1999). According to Dortch and Whitledge (1992), the following were the criteria for their molar ratios: (a) DIN : DIP ratio $<10$ and DSi : DIN ratio $>1$ for nitrogen $(\mathrm{N})$ limitation; (b) DIN : DIP ratio $>30$ and DSi : DIP ratio $>3$ for phosphorus (P) limitation; (c) and DSi : DIN ratio $<1$ and DSi : DIP ratio $<3$ for silicate $(\mathrm{Si})$ 
limitation. In this study, the nutrient limitation conditions were observed as absolute nutrient concentrations or/and molar ratios depending on the season (Table 2). Previous studies of biochemical composition in relation to nutrient limitation reported that the PRT production of phytoplankton was enhanced under abundant $\mathrm{N}$ conditions (Fabiano et al., 1993; Lee et al., 2009). In contrast, LIP production and storage were dominant (Shifrin and Chisholm, 1981; Harrison et al., 1990) and PRT contents decreased (Kilham et al., 1997; Lynn et al., 2000; Heraud at al., 2005) under Ndepleted conditions. High LIP contents have also been detected in phytoplankton under P or/and Si limitations (Lombardi and Wangersky, 1991; Lynn et al., 2000; Heraud et al., 2005; Sigee et al., 2007). Under N- or P-limited conditions, the triglyceride content (energy storage) increases and shifts from PRT to LIP metabolism since proteins are nitrogenous compounds, whereas LIP and CHO are non-nitrogenous substrates (Lombardi and Wangersky, 1991; Smith et al., 1997; Takagi et al., 2000). In our study, Si and P concentrations may not significantly impact the biochemical composition of phytoplankton. Si concentrations were almost above $2.0 \mu \mathrm{M}$, except in April 2013, during the study period. P limitation was observed based on the absolute concentration and molar ratios during study the period. However, under P limitation, phytoplankton can relocate the cellular $\mathrm{P}$ pool to maintain their $\mathrm{P}$ requirements for the maximum growth rate $(\mathrm{Cem}-$ bella et al., 1984; Ji and Sherrell, 2008). In this respect, we suggest that DIN could significantly impact the biochemical composition of phytoplankton in our study area. DIN was initially believed to be the most important limiting factor for phytoplankton growth in marine ecosystems (Ryther and Dunstan, 1971; Howarth, 1988). In fact, DIN was strongly positively correlated with PRT composition, whereas it was negatively correlated with LIP composition. The most DIN loading came from the freshwater input of the Seomjin River (Table 6; river input vs. $\mathrm{NH}_{4}$ and $\mathrm{NO}_{2}+\mathrm{NO}_{3} ; r=0.91$ and $0.55, p<0.01$, respectively), which influences the PRT and LIP synthesis and subsequently the macromolecular composition of phytoplankton. As a result, the amount of river input was also strongly correlated with PRT composition (Table 6 and Fig. 3). Therefore, DIN is an important controlling factor for biochemical composition, especially the PRT and LIP compositions of the phytoplankton in Gwangyang Bay.

Although irradiance is also known to be an important governing factor for biochemical composition, irradiance was not statistically correlated with biochemical pools in this study (Table 6). We measured PAR during our short incubation time (4-5h) for phytoplankton productivity as a parallel study. Since this short time of measured irradiance can be largely variable by local weather, it might not be enough to reflect and detect the change in the biochemical composition of phytoplankton with irradiance. The irradiance between April 2012 and April 2013 was largely various (approximately 10 times lower in April 2012 than in April 2013; Table 1). The increasing synthesis of proteins is found as light intensity decreases because a relatively lower irradiance saturation level is required for protein synthesis compared to that required for other biochemical components (Lee et al., 2009; Suárez and Marañón, 2003; Morris and Skea, 1978; Morris et al., 1974). Consistently, the protein compositions were significantly higher in April 2012 than in April 2013 ( $t$ test, $p<0.01$; Fig. 2 ) in this study. The proteins accounted for approximately 62 and $37 \%$ of the biochemical compositions in April 2012 and April 2013, respectively. However, the main reason for no consistent relationships between irradiance and the biochemical components along seasons might be the PAR measurements, as previously discussed.

The structure and composition of phytoplankton assemblages and species could have a significant influence on the seasonal variation in biochemical composition. Although we did not conduct a study of the phytoplankton community structure, there is a seasonal succession in the phytoplankton community structure in the bay. Previous studies showed that the dominant phytoplankton community was made up of diatoms with the dominant species Skeletonema spp. during summer and winter in Gwangyang Bay (Choi et al., 1998; Baek et al., 2015). Kim et al. (2009) also reported that diatom and dinoflagellate communities have experienced a considerable change because of increased nutrient loadings from both domestic sewage and industrial pollution during summer. Therefore, the seasonal change in the phytoplankton species composition and community structure could lead to a determination of the different biochemical pools on a seasonal basis.

However, other studies in different regions reported that environmental conditions, such as temperature, nutrients, and irradiance, are more important controlling factors in biochemical composition than variation in the phytoplankton community and species composition (Lindqvist and Lignell, 1997; Suárez and Marañón, 2003). In this study, we also concluded that DIN from river input was a primary governing factor for the seasonal variation in the biochemical composition of phytoplankton in Gwangyang Bay as discussed above.

\subsection{Total FM and energy content of POM in a global context}

Since there were no comparable data available in South Korea, we compared our results with other regions (Table 7), although they were conducted in different seasons and at different sampling depths. The PRT contents in this study were as high as in the Ross Sea (Fabiano and Pusceddu, 1998; Fabiano et al., 1999a), the Amundsen Sea (Kim et al., 2016), and the Humboldt Current System (Isla et al., 2010). A similar range of LIP contents was observed in Bedford Basin (Mayzaud et al., 1989), Yaldad Bay (Navarro et al., 1993), and the Humboldt Current System (Isla et al., 2010). The $\mathrm{CHO}$ contents were comparatively higher in this study than in other studies, except Bedford Basin (Mayzaud et al., 1989) and Yaldad Bay (Navarro et al., 1993). One of the high- 


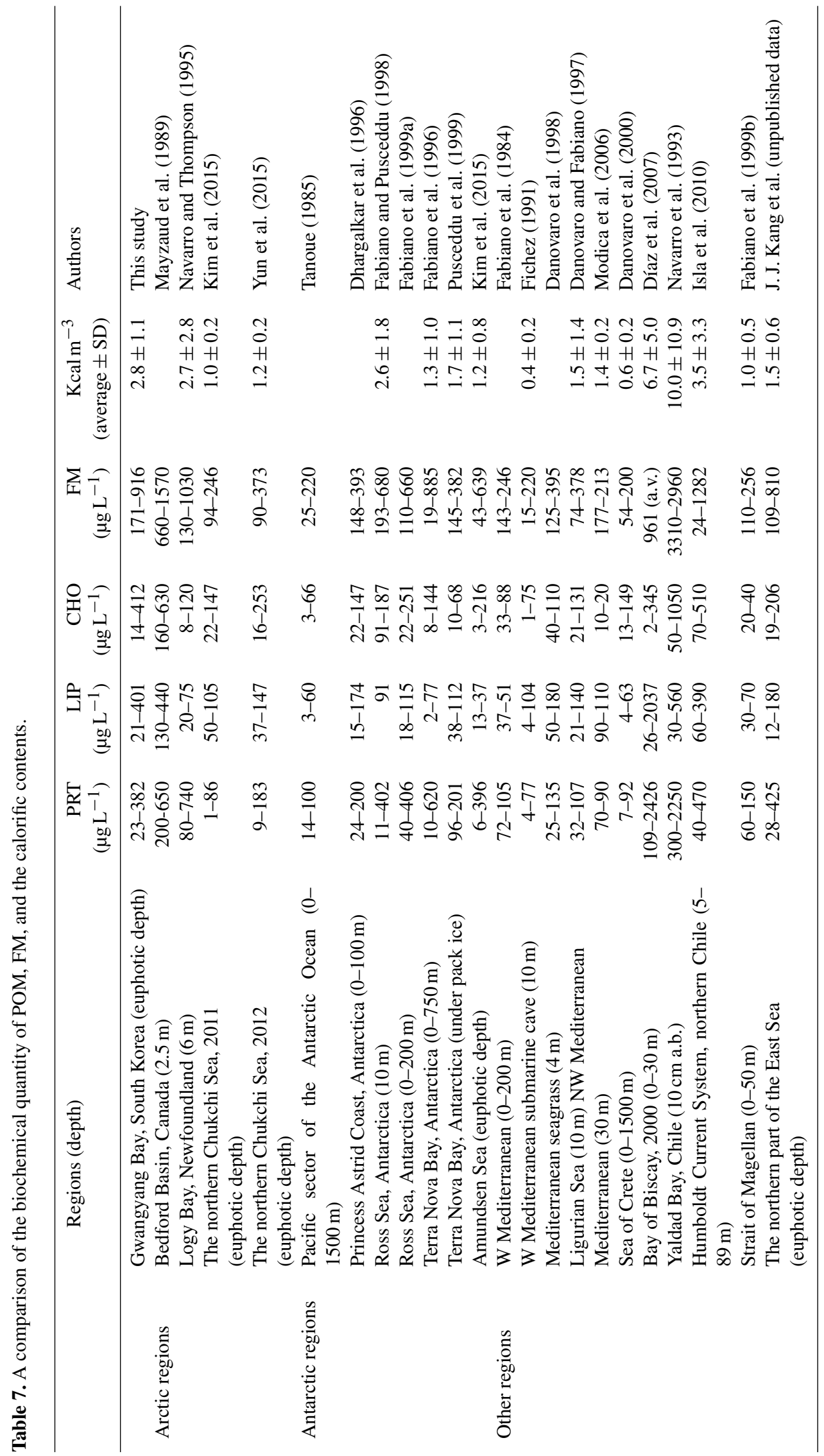


lights is that the calorific contents of FM in this study were generally higher than those in other areas, except in several regions. The FM values were comparatively higher than in other regions, such as the northern Chukchi Sea (Kim et al., 2015; Yun et al., 2015), the Ross Sea (Fabiano et al., 1996, 1999a; Fabiano and Pusceddu, 1998; Pusceddu et al., 1999), the Amundsen Sea (Kim et al., 2016), and the northern part of the East Sea (J. J. Kang et al., unpublished). They were similar to the Humboldt Current System, which is known as an important spawning site for pelagic fish and the highest abundance of anchovy eggs (Isla et al., 2010). Actually, the southern coastal sea (including our study area) in Korea represents calm seas, an indented coastline, and numerous bays, which have high habitat diversities for fish and shellfish (Kwak et al., 2012) with favorable conditions for mariculture (Kwon et al., 2004). The high quantity of FM and the calorific contents of POM found in this study reflected the good nutritive conditions of the primary food materials, mainly provided by phytoplankton, for the maintenance of productive shellfish and fish populations in Gwangyang Bay.

Data availability. Data are available and can be requested from the corresponding author (sanglee@pusan.ac.kr).

Competing interests. The authors declare that they have no conflict of interest.

Acknowledgements. We thank the anonymous reviewers who greatly improved an earlier version of the manuscript. This research was supported by the project "Long-term change of structure and function in marine ecosystems of Korea" funded by the Korean Ministry of Oceans and Fisheries.

Edited by: G. Herndl

Reviewed by: two anonymous referees

\section{References}

Baek, S., Kim, D., Hyun, B., Choi, H., and Kim, Y.: Characteristics of horizontal community distribution and nutrient limitation on growth rate of phytoplankton during a winter in Gwangyang Bay, Korea, Ocean and Polar Research, 33, 99-111, 2011.

Baek, S. H., Kim, D., Son, M., Yun, S. M., and Kim, Y. O.: Seasonal distribution of phytoplankton assemblages and nutrient-enriched bioassays as indicators of nutrient limitation of phytoplankton growth in Gwangyang Bay, Korea, Estuar. Coast. Shelf S., 163, 265-278, 2015.

Bligh, E. G. and Dyer, W. J.: A rapid method of total lipid extraction and purification, Can. Jo. Biochem. Phys., 37, 911-917, 1959.

Boëchat, I. G. and Giani, A.: Seasonality affects diel cycles of seston biochemical composition in a tropical reservoir, J. Plankton Res., 30, 1417-1430, 2008.
Cauwet, G.: Organic-chemistry of sea-water particulates concepts and developments, Oceanol. Acta, 1, 99-105, 1978.

Cembella, A. D., Antia, N. J., Harrison, P. J., and Rhee, G.: The utilization of inorganic and organic phosphorous compounds as nutrients by eukaryotic microalgae: a multidisciplinary perspective: part 2, Crit. Rev. Microbiol., 11, 13-81, 1984.

Cho, K., Wui, I., and Choi, C.: Ecological study of phytoplankton in the Kwang-Yang Bay, Korean J. Environ. Biol, 12, 137-150, 1994.

Choi, S. and Noh, I.: A Study of the Environmental Characteristics and the Structure of the Phytoplankton Community, The Korean S. Marine Environ. Eng., Spring meeting, May, Ansan, Korea, 213-220, 1998.

Cloern, J. E. and Nichols, F. H.: Time scales and mechanisms of estuarine variability, a synthesis from studies of San Francisco Bay, Hydrobiologia, 129, 229-237, 1985.

Cuhel, R. L. and Lean, D. R.: Influence of light intensity, light quality, temperature, and daylength on uptake and assimilation of carbon dioxide and sulfate by lake plankton, Can. J. Fish. Aquat. Sci., 44, 2118-2132, 1987.

Danovaro, R. and Fabiano, M.: Seasonal changes in quality and quantity of food available for benthic suspension-feeders in the Golfo Marconi (North-western Mediterranean), Estuar. Coast. Shelf S., 44, 723-736, 1997.

Danovaro, R., Della Croce, N., and Fabiano, M.: Biochemical composition of particulate organic matter and bacterial dynamics at the sediment-water interface in a Mediterranean seagrass system, in: Eutrophication in Planktonic Ecosystems: Food Web Dynamics and Elemental Cycling, Springer, the Netherlands, 241251, 1998.

Danovaro, R., Dell'Anno, A., Pusceddu, A., Marrale, D., Della Croce, N., Fabiano, M., and Tselepides, A.: Biochemical composition of pico-, nano-and micro-particulate organic matter and bacterioplankton biomass in the oligotrophic Cretan Sea (NE Mediterranean), Prog. Oceanogr., 46, 279-310, 2000.

Dhargalkar, V. K., Matondkar, S. P., and Verlecar, X. N.: Seasonal variations in carbon budget in water column off Princess Astrid coast, Antarctica, Department of Ocean Development, Scientific report, India, 10, 259-266, 1996.

Díaz, E., Valencia, V., and Villate, F.: Size-fractionated seston abundance and biochemical composition, over the anchovy spawning period in the Basque shelf (Bay of Biscay), during years 2000 and 2001, J. Exp. Mar. Biol. Ecol., 341, 45-59, 2007.

Dortch, Q. and Whitledge, T. E.: Does nitrogen or silicon limit phytoplankton production in the Mississippi River plume and nearby regions?, Cont. Shelf Res., 12, 1293-1309, 1992.

Dubois, M., Gilles, K. A., Hamilton, J. K., Rebers, P., and Smith, F.: Colorimetric method for determination of sugars and related substances, Anal. Chem., 28, 350-356, 1956.

Elrifi, I. R. and Turpin, D. H.: Steady-state luxury consumption and the concept of optimum nutrient ratios: A study with phosphate and nitrate limited Selenastrum Minutum (Chlorophyta), J. Phycol., 21, 592-602, 1985.

Eppley, R. W., Rogers, J. N., and McCarthy, J. J.: Half-saturation constants for uptake of nitrate and ammonium by marine phytoplankton, Limnol. Oceanogr., 14, 912-920, 1969.

Fabiano, M. and Pusceddu, A.: Total and hydrolizable particulate organic matter (carbohydrates, proteins and lipids) at a coastal 
station in Terra Nova Bay (Ross Sea, Antarctica), Polar Biol., 19, 125-132, 1998.

Fabiano, M., Zavattarelli, M., and Palmero, S.: Observations sur la matiere organique particulaire en Mer Ligure (chlorophylle, proteines, glucides, lipides), Tethys, 11, 133-140, 1984.

Fabiano, M., Povero, P., and Danovaro, R.: Distribution and composition of particulate organic matter in the Ross Sea (Antarctica), Polar Biol., 13, 525-533, 1993.

Fabiano, M., Povero, P., and Danovaro, R.: Particulate organic matter composition in Terra Nova Bay (Ross Sea, Antarctica) during summer 1990, Antarct. Sci., 8, 7-14, 1996.

Fabiano, M., Danovaro, R., and Povero, P.: Vertical distribution and biochemical composition of pico-and microparticulate organic matter in the Ross Sea (Antarctica), in: Oceanography of the Ross Sea Antarctica, Springer, Milan, 233-246, 1999a.

Fabiano, M., Povero, P., Danovaro, R., and Misic, C.: Particulate organic matter composition in a semi-enclosed Periantarctic system: the Straits of Magellan, Sci. Mar., 63, 89-98, 1999b.

Fichez, R.: Suspended particulate organic matter in a Mediterranean submarine cave, Mar. Biol., 108, 167-174, 1991.

Fisher, T. R., Harding Jr., L. W., Stanley, D. W., and Ward, L. G.: Phytoplankton, nutrients, and turbidity in the Chesapeake, Delaware, ad Hudson Estuaries, Estuar. Coast. Shelf S., 27, 6193, 1988.

Goldman, J. C., McCarthy, J. J., and Peavey, D. G.: Growth rate influence on the chemical composition of phytoplankton in oceanic waters, Nature, 279, 210-215, doi:10.1038/279210a0, 1979.

Graf, G.: Benthic-pelagic coupling: A benthic view, Oceanogr. Mar. Biol., 30, 149-190, 1992.

Hama, T., Miyazaki, T., Ogawa, Y., Iwakuma, T., Takahashi, M., Otsuki, A., and Ichimura, S.: Measurement of photosynthetic production of a marine phytoplankton population using a stable ${ }^{13} \mathrm{C}$ Isotope, Mar. Biol., 73, 31-36, 1983.

Harrison, P., Thompson, P., and Calderwood, G.: Effects of nutrient and light limitation on the biochemical composition of phytoplankton, J. Appl. Phycol., 2, 45-56, 1990.

Heraud, P., Wood, B. R., Tobin, M. J., Beardall, J., and McNaughton, D.: Mapping of nutrient-induced biochemical changes in living algal cells using synchrotron infrared microspectroscopy, FEMS Microbiol. Lett., 249, 219-225, 2005.

Howarth, R. W.: Nutrient limitation of net primary production in marine ecosystems, Annu. Rev. Ecol. Syst., 19, 89-110, 1988.

Isla, E., Homs, P., Sañé, E., Escribano, R., Claramunt, G., and Teixidó, N.: Biochemical composition of seston in two upwelling sites within the Humboldt Current System (21 S to $23 \mathrm{~S}$ ): Summer conditions, J. Marine Syst., 82, 61-71, 2010.

Jang, P., Lee, W., Jang, M., Lee, J., Lee, W., Chang, M., Hwang, K., and Shin, K.: Spatial and temporal distribution of inorganic nutrients and factors controlling their distributions in Gwangyang Bay, Ocean and Polar Research, 27, 359-379, 2005.

Ji, Y. and Sherrell, R. M.: Differential effects of phosphorus limitation on cellular metals in Chlorella and: I Microcystis, Limnol. Oceanogr., 53, 1790-1804, 2008.

Justić, D., Rabalais, N. N., Turner, R. E., and Dortch, Q.: Changes in nutrient structure of river-dominated coastal waters: stoichiometric nutrient balance and its consequences, Estuar. Coast. Shelf S., 40, 339-356, 1995.
Kakinuma, M., Shibahara, N., Ikeda, H., Maegawa, M., and Amano, H.: Thermal stress responses of a sterile mutant of Ulva pertusa (Chlorophyta), Fisheries Sci., 67, 287-294, 2001.

Kakinuma, M., Coury, D., Kuno, Y., Itoh, S., Kozawa, Y., Inagaki, E., Yoshiura, Y., and Amano, H.: Physiological and biochemical responses to thermal and salinity stresses in a sterile mutant of Ulva pertusa (Ulvales, Chlorophyta), Mar. Biol., 149, 97-106, 2006.

Kang, C. K., Lee, P. Y., Kim, P. J., and Choi, H. G.: Daily variation of particulate organic carbon in Wonmun Bay on the south coast of Korea in late summer, J. Kor. Fis. Soc., 26, 279-287, 1983.

Kang, C. K., Kim, J. B., Lee, K., Kim, J. B., Lee, P., and Hong, J.: Trophic importance of benthic microalgae to macrozoobenthos in coastal bay systems in Korea: dual stable $\mathrm{C}$ and $\mathrm{N}$ isotope analyses, Mar. Ecol.-Prog. Ser., 259, 79-92, 2003.

Khotimchenko, S. V. and Yakovleva, I. M.: Lipid composition of the red alga Tichocarpus crinitus exposed to different levels of photon irradiance, Phytochemistry, 66, 73-79, 2005.

Kilham, S., Kreeger, D., Goulden, C., and Lynn, S.: Effects of nutrient limitation on biochemical constituents of Ankistrodesmus falcatus, Freshwater Biol., 38, 591-596, 1997.

Kim, B. K., Lee, J. H., Yun, M. S., Joo, H., Song, H. J., Yang, E. J., Chung, K. H., Kang, S., and Lee, S. H.: High lipid composition of particulate organic matter in the northern Chukchi Sea, 2011, Deep-Sea Res. Pt. II, 120, 72-81, 2015.

Kim, B. K., Lee, J. H., Joo, H., Song, H. J., Yang, E. J., Lee, S. H., and Lee, S. H.: Macromolecular compositions of phytoplankton in the Amundsen Sea, Antarctica, Deep-Sea Res. Pt. II, 123, 4249, 2016

Kim, S., Moon, C., Cho, H., and Lim, D.: Dinoflagellate cysts in coastal sediments as indicators of eutrophication: a case of Gwangyang Bay, South Sea of Korea, Estuar. Coast., 32, 1225$1233,2009$.

Kwak, S., Huh, S. and Kim, H.: Change in Fish Assemblage Inhabiting Around Dae Island in Gwangyang Bay, Korea, Journal of the Korean Society of Marine Environment \& Safety, 18, 175184,2012

Kwon, H., Lee, C., Jun, B., Weon, S., and Koopman, B.: Recycling waste oyster shells for eutrophication control, Resour. Conserv. Recy., 41, 75-82, 2004.

Kwon, K. Y., Moon, C. H., Kang, C. K., and Kim, Y. N.: Distribution of particulate organic matters along salinity gradients in the Seomjin river estuary, J. Kor. Fis. Soc., 35, 86-96, 2002.

Lancelot, C. and Billen, G.: Carbon-nitrogen relationships in nutrient metabolism of coastal marine ecosystems, Advances in Aquatic Microbiology, 3, 263-321, 1985.

Lee, P. Y., Park, C., Moon, C., Park, M., and Gwon, K.: Biomass and species composition of phytoplankton and zooplankton along the salinity gradients in the Seomjin River Estuary, The Sea, 6, 93 102, 2001a.

Lee, P. Y., Kang, C. K., Choi, W. J., and Yang, H. S.: Temporal and spatial variations of particulate organic matter in the southeastern coastal bays of Korea, J. Kor. Fis. Soc., 34, 57-69, 2001 b.

Lee, S. H. and Whitledge, T. E.: Primary and new production in the deep Canada Basin during summer 2002, Polar Biol., 28, 190 197, 2005.

Lee, S. H., Kim, H., and Whitledge, T. E.: High incorporation of carbon into proteins by the phytoplankton of the Bering Strait and Chukchi Sea, Cont. Shelf Res., 29, 1689-1696, 2009. 
Lindqvist, K. and Lignell, R.: Intracellular partitioning of ${ }^{14} \mathrm{CO}_{2}$ in phytoplankton during a growth season in the northern Baltic, Mar. Ecol.-Prog. Ser., 152, 41-50, 1997.

Lobbes, J. M., Fitznar, H. P., and Kattner, G.: Biogeochemical characteristics of dissolved and particulate organic matter in Russian rivers entering the Arctic Ocean, Geochim. Cosmochim. Ac., 64, 2973-2983, 2000.

Lombardi, A. and Wangersky, P.: Influence of phosphorus and silicon on lipid class production by the marine diatom Chaetoceros gracilis grown in turbidostat cage cultures, Mar. Ecol.-Prog. Ser., 77, 39-47, 1991.

Lowry, O. H., Rosebrough, N. J., Farr, A. L., and Randall, R. J.: Protein measurement with the Folin phenol reagent, J. Biol. Chem., 193, 265-275, 1951.

Lynn, S. G., Kilham, S. S., Kreeger, D. A., and Interlandi, S. J.: Effect of nutrient availability on the biochemical and elemental stoichiometry in the freshwater diatom Stephanodiscus minutulus (Bacillariophyceae), J. Phycol., 36, 510-522, 2000.

Marsh, J. B. and Weinstein, D. B.: Simple charring method for determination of lipids, J. Lipid. Res., 7, 574-576, 1966.

Mayzaud, P., Chanut, J. P., and Ackman, R. G.: Seasonal changes of the biochemical composition of marine particulate matter with special reference to fatty acids and sterols, Mar. Ecol.-Prog. Ser., 56, 189-204, 1989.

Min, J. O., Ha, S. Y., Choi, B. H., Chung, M. H., Yoon, W. D., Lee, J. S. and Shin, K. H.: Primary productivity and pigments variation of phytoplankton in the Seomjin River estuary during rainy season in summer, Korean J. Limnol, 44, 303-313, 2011.

Mock, T. and Kroon, B. M.: Photosynthetic energy conversion under extreme conditions - II: the significance of lipids under light limited growth in Antarctic sea ice diatoms, Phytochemistry, 61, 53-60, 2002.

Modica, A., Scilipoti, D., La Torre, R., Manganaro, A., and Sarà, G.: The effect of mariculture facilities on biochemical features of suspended organic matter (southern Tyrrhenian, Mediterranean), Estuar. Coast. Shelf S., 66, 177-184, 2006.

Morris, I. and Skea W.: Products of photosynthesis in natural populations of marine phytoplankton from the Gulf of Maine, Mar. Biol., 47, 303-312, 1978.

Morris, I., Glover, H., and Yentsch, C.: Products of photosynthesis by marine phytoplankton: the effect of environmental factors on the relative rates of protein synthesis, Mar. Biol., 27, 1-9, 1974.

Navarro, J. and Thompson, R.: Seasonal fluctuations in the size spectra, biochemical composition and nutritive value of the seston available to a suspension-feeding bivalve in a subarctic environment, Mar. Ecol.-Prog. Ser., 125, 95-106, 1995.

Navarro, J., Clasing, E., Urrutia, G., Asencio, G., Stead, R., and Herrera, C.: Biochemical composition and nutritive value of suspended particulate matter over a tidal flat of southern Chile, Estuar. Coast. Shelf S., 37, 59-73, 1993.

Nelson, D. M. and Smith, W. O.: Phytoplankton bloom dynamics of the western Ross Sea ice edge - II. Mesoscale cycling of nitrogen and silicon, Deep-Sea Res. Pt. I, 33, 1389-1412, 1986.

Oliveira, M. D., Monteiro, M., Robbs, P., and Leite, S.: Growth and chemical composition of Spirulina maxima and Spirulina platensis biomass at different temperatures, Aquacult. Int., 7, 261-275, 1999.
Parsons, T. R., Maita, Y., and Lalli, C. M.: A manual of biological and chemical methods for seawater analysis, Publ. Pergamon Press, Oxford, 1984.

Pirt, S. J.: Principles of microbe and cell cultivation, Blackwell Scientific Publications, Oxford, UK, 1975.

Poole, H. H. and Atkins, W. R. G.: Photo-electric measurements of submarine illumination throughout the year, J. Mar. Biol. Assoc. UK, 16, 297-324, 1929.

Pusceddu, A., Cattaneo-Vietti, R., Albertelli, G., and Fabiano, M.: Origin, biochemical composition and vertical flux of particulate organic matter under the pack ice in Terra Nova Bay (Ross Sea, Antarctica) during late summer 1995, Polar Biol., 22, 124-132, 1999.

Redfield, A. C., Ketchum, B. H., and Richards, F. A.: The influence of organisms on the composition of seawater, Comparative and Descriptive Oceanography, 2, MN Hill, 26-77, 1963.

Rice, A., Thurston, M., and Bett, B.: The IOSDL DEEPSEAS programme: introduction and photographic evidence for the presence and absence of a seasonal input of phytodetritus at contrasting abyssal sites in the northeastern Atlantic, Deep-Sea Res. Pt I, 41, 1305-1320, 1994.

Rivkin, R. B. and Voytek, M. A.: Photoadaptations of photosynthesis and carbon metabolism by phytoplankton from McMurdo Sound, Antarctica. 1. Species-specific and community responses to reduced irradiances, Limnol. Oceanogr., 32, 249-259, 1987.

Roelke, D., Eldridge, P., and Cifuentes, L.: A model of phytoplankton competition for limiting and nonlimiting nutrients: implications for development of estuarine and nearshore management schemes, Estuaries, 22, 92-104, 1999.

Ryther, J. H. and Dunstan, W. M.: Nitrogen, phosphorus, and eutrophication in the coastal marine environment, Science, 171, 1008-1013, 1971

Savoye, N., Aminot, A., Treguer, P., Fontugne, M., Naulet, N., and Kérouel, R.: Dynamics of particulate organic matter $\delta^{15} \mathrm{~N}$ and $\delta^{13} \mathrm{C}$ during spring phytoplankton blooms in a macrotidal ecosystem (Bay of Seine, France), Mar. Ecol.-Prog. Ser., 255, 27-41, 2003.

Shaha, D. C. and Cho, Y.-K.: Comparison of empirical models with intensively observed data for prediction of salt intrusion in the Sumjin River estuary, Korea, Hydrol. Earth Syst. Sci., 13, 923 933, doi:10.5194/hess-13-923-2009, 2009.

Shifrin, N. S. and Chisholm, S. W.: Phytoplankton lipids: interspecific differences and effects of nitrate silicate and light-dark cycles, J. Phycol., 17, 374-384, 1981.

Sigee, D. C., Bahrami, F., Estrada, B., Webster, R. E., and Dean, A. P.: The influence of phosphorus availability on carbon allocation and P quota in Scenedesmus subspicatus: a synchrotron-based FTIR analysis, Phycologia, 46, 583-592, 2007.

Smith, A. and Morris, I.: Pathways of carbon assimilation in phytoplankton from the Antarctic Ocean, Limnol. Oceanogr., 25, 865872, 1980.

Smith, R., Gosselin, M., and Taguchi, S.: The influence of major inorganic nutrients on the growth and physiology of high arctic ice algae, J. Marine Syst., 11, 63-70, 1997.

Smith, R. E., Clement, P., and Head, E.: Biosynthesis and photosynthate allocation patterns of arctic ice algae, Limnol. Oceanogr., 34, 591-605, 1989.

Sterner, R. W., Elser, J. J., Fee, E. J., Guildford, S. J., and Chrzanowski, T. H.: The light: nutrient ratio in lakes: the balance 
of energy and materials affects ecosystem structure and process, Am. Nat., 150, 663-684, 1997.

Suárez, I. and Maranón, E.: Photosynthate allocation in a temperate sea over an annual cycle: the relationship between protein synthesis and phytoplankton physiological state, J. Sea Res., 50, 285-299, 2003.

Takagi, M., Watanabe, K., Yamaberi, K., and Yoshida, T.: Limited feeding of potassium nitrate for intracellular lipid and triglyceride accumulation of Nannochloris sp. UTEX LB1999, Appl. Microbiol. Biot., 54, 112-117, 2000.

Tanoue, E.: Distribution and chemical composition of particulate organic matter in the Pacific sector of the Antarctic Ocean, T. Tokyo Univ. Fish., 6, 43-57, 1985.

Tomaselli, L., Giovannetti, L., Sacchi, A., and Bocci, F.: Effects of temperature on growth and biochemical composition in Spirulina platensis strain M2, Algal Biotechnology, Elsevier Applied Science, London, 303-314, 1988.

Thornton, S. F. and McManus, J.: Application of organic carbon and nitrogen stable isotope and $\mathrm{C} / \mathrm{N}$ ratios as source indicators of organic matter provenance in estuarine systems: evidence from the Tay estuary, Scotland, Estuar. Coast. Shelf S., 38, 219-233, 1994.
Ventura, M., Liboriussen, L., Lauridsen, T., Søndergaard, M., and Jeppesen, E.: Effects of increased temperature and nutrient enrichment on the stoichiometry of primary producers and consumers in temperate shallow lakes, Freshwater Biol., 53, 14341452, 2008.

Wetz, M. S. and Yoskowitz, D. W.: An "extreme" future for estuaries? Effects of extreme climatic events on estuarine water quality and ecology, Mar. Pollut. Bull., 69, 7-18, 2013.

Winberg, G.: Symbols, units and conversion factors in studies of fresh water productivity, International Biological Programme Control Office, London, 1971.

Yang, S. R., Song, H. S., Kim, K., Park, C., and Moon, C.: Changes in environmental factors and primary productivity in the Seomjin River Estuary, The Sea, 10, 164-170, 2005.

Yun, M. S., Lee, D. B., Kim, B. K., Kang, J. J., Lee, J. H., Yang, E. J., Park, W. G., Chung, K. H., and Lee, S. H.: Comparison of phytoplankton macromolecular compositions and zooplankton proximate compositions in the northern Chukchi Sea, Deep-Sea Res. Pt. II, 120, 82-90, 2015. 